\section{Scientific journal}

\section{PHYSICAL AND MATHEMATICAL EDUCATION}

Has been issued since 2013.

Науковий журнал

ФІЗИКО-МАТЕМАТИЧНА ОСВІТА

Видається з 2013.
ISSN 2413-158X (online)

ISSN 2413-1571 (print)

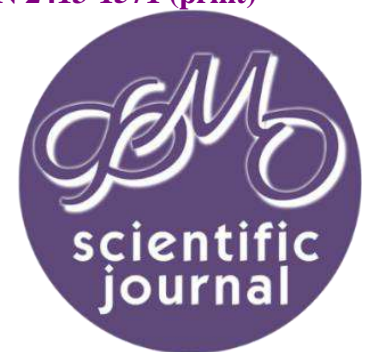

Семеніхіна О.В., Юрченко А.О., Удовиченко О.М., Литвиненко О.В. Педагогічний дизайн і підготовка майбутніх фахівців його використовувати. Фізико-математична освіта. 2020. Випуск 4(26). С. 30-33.

Semenikhina O., Yurchenko A., Udovychenko, O. Litvinenko O. Pedagogical design and preparation of future specialists for use. Physical and Mathematical Education. 2020. Issue 4(26). P. 30-33.

DOI 10.31110/2413-1571-2020-026-4-005

O. Semenikhina

Makarenko Sumy State Pedagogical University, Ukraine ORCID: 0000-0002-3896-8151

A. Yurchenko

Makarenko Sumy State Pedagogical University, Ukraine ORCID: 0000-0002-6770-186X

0. Udovychenko

Makarenko Sumy State Pedagogical University, Ukraine ORCID: 0000-0002-3401-3251

O. Litvinenko

Makarenko Sumy State Pedagogical University, Ukraine

\title{
PEDAGOGICAL DESIGN AND PREPARATION OF FUTURE SPECIALISTS FOR USE
}

\section{ABSTRACT}

Formulation of the problem. The article describes the Ukrainian experience of preparing future specialista for pedagogical design.

Materials and method: theoretical: modeling - to substantiate and develop a model of forming the readiness of future specialists -pedagogues to pedagogical design, to identify pedagogical conditions that contribute to the preparation of future specialists for pedagogical design; empirical: diagnostic to find out the effectiveness of pedagogical conditions of forming the readiness of future specialists to pedagogical design; pedagogical experiment (ascertaining, forming) - to check the effectiveness of the model of formation of future specialists' readiness for pedagogical design; statistical - analysis of the obtained data with the help of mathematical statistics methods for processing and interpretation of experimental results.

Results. In particular, the state of development of the problem in the theory and practice of Ukrainian vocational training is described, the essence of pedagogical design is revealed, the essence and structure of readiness of future specialists to pedagogical design are specified; described diagnostic tools for determining the level of readiness of future specialists for pedagogical design; developed and theoretically substantiated model of formation of future specialists' readiness for pedagogical design; the results of the statistical analysis of its effectiveness are described.

Conclusions. The effectiveness of the introduced model of forming the readiness of future specialists for pedagogical design was confirmed. The prospects for further scientific research are connected with the development of a holistic concept of project pedagogical activity in higher education, creation of a structural and functional model of project activity of an educational institution in Ukraine.

Keywords: pedagogical design, preparation of future specialists, preparation, vocational training, model.

\section{INTRODUCTION}

Transformational processes in Ukrainian society related to integration into the European community. The active shifts in the economic, political and social spheres of social life due to this necessitated the renewal of higher pedagogical education. The purpose of such education is to train professionals in the fields of engineering and pedagogy who, in their professional activities, will apply engineering and pedagogical knowledge in non-standard, constantly changing professional situations and at the same time will be ready for professional development, self-development and self-improvement.

To a large extent, the successful solution of their professional tasks depends on the pedagogical design, which allows to successfully transform the pedagogical idea into a technological sequence of pedagogical actions that correspond to a specific expected result. In this regard, it is important to research scientifically the content, methods, forms and means of forming the readiness future specialists for pedagogical design.

The peculiarities of professional training of specialistsare covered in various scientific works, in particular, the following are investigated: peculiarities of formation of pedagogical orientation of engineers-pedagogues (Ganopolsky, 1996), organizational and pedagogical conditions of adaptation of future engineers-pedagogues (Gura, 2004) knowledge and skills of 
future specialistsin the process of teaching computer disciplines (Gromov, 2007), theoretical and methodological foundations of professional training of future specialists of computer profile (Gorbatiuk, 2011), theoretical and methodological foundations of professional training of future teachers (Semenog et al., 2019; Semenikhina et al., 2020; Yurchenko et al., 2017; Semenikhina \& Drushlyak, 2017; Semenikhina \& Yurchenko \& Udovychenko, 2020) organizational and pedagogical conditions of preparation of competitive specialist in engineering and pedagogical educational institutions (Romanovska, 2011), specifics of professional training of future engineers-pedagogues to designing clothes by means of information technologies (Skvarok, 2015), peculiarities of forming readiness for readiness teachers to professional activity by means of information and communication technologies (Potapchuk, 2016).

The dissertation researches in which features of psychological and pedagogical designing of educational process (Kobernyk, 2000), features of preparation of future teachers of humanitarian profile for pedagogical design (Podobedova, 2005), theoretical and methodological principles of designing innovative pedagogical pedagogical systems are of value, interdisciplinary synthesis (Dokuchaeva, 1994).

However, there is no comprehensive research on the problem of preparing future specialists for pedagogical design in national pedagogy.

Theoretical analysis of the results of scientific and pedagogical researches, studying of practical experience of pedagogical specialtie`s preparation allowed to reveal a number of contradictions, in particular between:

- the needs of society for pedagogical workers who have a high level of competence in the field of project activity, and the real state of preparation of future specialists for pedagogical design;

- the need for purposeful preparation of future specialists for pedagogical design and insufficient theoretical substantiation of this process;

- the need to prepare future specialists for pedagogical design and the lack of methodological support for the formation of students' knowledge and skills from the basics of pedagogical design.

Therefore, the urgency of the problem, its lack of theoretical development and practical importance, the need to overcome these contradictions determined the purpose of the research: scientific substantiation, theoretical development and experimental verification of the model of formation of future specialists' readiness for pedagogical design.

According to the set goal, the study identified the following tasks.

1. To analyze the state of development of the problem of preparation of future specialists for pedagogical design in pedagogical theory and practice, to reveal the essence of pedagogical design.

2. To clarify the nature and structure of the readiness of future specialists for pedagogical design; to define criteria, indicators and levels of readiness of future specialists for pedagogical design.

3. To develop and theoretically substantiate the model of forming the readiness of future specialists for pedagogical design.

4. To test experimentally the effectiveness of the developed model of forming the readiness of future specialists for pedagogical design.

\section{METHODS OF THE RESEARCH}

The following research methods were used to solve these tasks:

- theoretical: analysis, generalization, systematization of philosophical, psycho-pedagogical, methodological literature, normative-legal documents regulating the activity of university, scientific works in the field of vocational education in order to determine the state of development of the problem under study; classification, systematization and synthesis of scientific data for the study of the nature and structural components, criteria, indicators and levels of readiness of future specialists to pedagogical design; modeling to substantiate and develop a model of forming the readiness of future specialists to pedagogical design, to identify pedagogical conditions that contribute to the preparation of future specialists for pedagogical design;

- empirical: diagnostic (surveys, observations, conversations, questionnaires, testing) - to find out the effectiveness of pedagogical conditions of forming the readiness of future specialists to pedagogical design; study of pedagogical experience in the professional training of future specialists; peer review - to obtain independent evaluations of the pedagogical phenomenon under study; studying the results of educational and cognitive activities of students - to find out their attitude to forming readiness for pedagogical design; pedagogical experiment (ascertaining, forming) - to check the effectiveness of the model of formation of future specialists' readiness for pedagogical design;

- statistical: analysis of the obtained data with the help of mathematical statistics methods for processing and interpretation of experimental results.

\section{RESULTS OF RESEARCH}

On the basis of the analysis of legislative documents, the study of domestic and foreign experience, it is found out that under the influence of social order the role of pedagogical education increases, which provides training, retraining and advanced training of teachers of professional and general technical disciplines for institutions of the system of vocational, professional and professional vocational education.

Based on the use of theoretical methods of analysis, systematization and generalization of a wide range of scientific sources, pedagogical design is defined as an objectively complex multistage activity of the teacher, which is associated with the creation of models of pedagogical systems and processes at different levels and is embodied as a series of sequential steps and actions: forecasting ( designing a project idea: what, where, when to do to create a project), modeling (creating a model: how, under what conditions the project will be created), designing (creating a coherent design) structure: when and in what sequence the project is created, whether there is a deviation, what are the reasons to be done to prevent their occurrence) and 
approbations (implementation of the project: what is the end result of the design, where and how the project can be used in future activities ).

Thus, in the process of analysis it is determined that the preparation of future specialistsfor pedagogical design should be directed to: a) formation of future specialistsmotives for pedagogical design; b) formation of basic (subject and pedagogical) knowledge and skills in the process of professional training; $\mathrm{c}$ ) formation of specific (design) knowledge and skills of pedagogical specialists on the material of vocational training disciplines, taking into account the content of specialization; d) ensuring adequate self-assessment by future specialistsof the level of formation of design knowledge and skills and correction of the process of their self-formation.

The scientific analysis made it possible to determine the readiness of future specialists for pedagogical designing as a holistic, stable, integral personal formation, which is subject to purposeful formation of a set of design knowledge and skills and finds manifestation in interrelated and inter-conditioned components, activity and acmeology).

The motivational-value component includes motives, goals, needs to acquire and carry out pedagogical design, selfimprovement, self-education, self-development, formation of the necessary value-orientations, and stimulation of creative manifestation of the teacher in professional activity.

The cognitive component encompasses a set of subjects and pedagogical knowledge and skills that are important in professional activity, and the ability to carry out pedagogical design. The formation of such a complex of knowledge and skills contributes to the development of professionally important qualities necessary for the performance of various pedagogical functions and design in particular.

The practical-activity component is formed as a complex of design knowledge and skills, which is consciously acquired through active assimilation of the content of future pedagogical activity and is personally significant.

The acmeological component is a set of knowledge, skills and abilities for self-improvement, self-development, selfeducation through the pedagogical design of general and professional development.

Taking into account the modeling method, the results of the analysis of pedagogical and psychological researches on the algorithm of designing innovative pedagogical systems, a model of forming the readiness of future pedagogues to pedagogical design was developed.

In the program-organizational unit the program of pedagogical experiment was developed, methodical tools and contingent of students were defined. The block includes criteria and indicators agreed in order with the components of the future teacher' readiness for pedagogical design:

1) communicative (an indicator - the presence of a system of incentives that determine the activity of the individual) and reflexive (an indicator - the presence of a persistent desire for success and the desire to avoid failure) criteria;

2) content (indicator - success), informational (indicator - development of ability to choose the most essential information), creative (indicator - availability of ability to creativity) criteria;

3) practical (indicator - the formation of professional skills and skills essential for pedagogical design), activity (indicator - the ability to apply knowledge in practice), organizational and executive (indicator - the ability to control the performance of tasks) criteria;

4) volitional (indicator - ability to overcome difficulties in achieving the goal), integrative-personal (indicator professionally important qualities) criteria.

To better reflect the degree of readiness of future specialists for pedagogical design, we have three levels: low, medium and high.

Determining the effectiveness of the model of forming the readiness of future specialiststo pedagogical design in the course of their training in the HEA is due to the introduction of an analytical-correction block in the model. This block provides for the control, analysis and correction of the experimental work and the results obtained.

At the ascertaining stage of the pedagogical experiment 254 students, 16 teachers who train future specialists, 31 graduates, 12 of whom are masters of industrial training. The analysis of the obtained data from the questionnaires and surveys makes it possible to conclude that in the professional training of future specialists, the measures for the formation of knowledge and skills in pedagogical design, motivation for pedagogical activity and quality for this profession are insufficiently implemented.

In general, the results of diagnostics determine that the level of formation of components of the readiness of future specialists for pedagogical design at the beginning of the experiment is generally low, which requires improvement of students' preparation for designing professional tasks and actions, which is suggested within the framework of a design experiment.

\section{DISCUSSION}

The purpose of the four-year formative experiment was to develop and implement the content, methods, tools and forms of training future specialists for pedagogical design in the process of studying professional disciplines. Preparation for the design of professional activities was carried out in experimental groups, the control group instead was trained in the usual curriculum. The effectiveness of the developed model was verified by determining the level of preparedness of future specialists for pedagogical design (similar sections at the previous stage).

Qualitative and quantitative changes for each indicator are reflected in the dynamics of the levels of readiness of future specialistsof the control and experimental groups (the analysis was made at the significance level of 0.05 ). Thus, the effectiveness of the introduced model of forming the readiness of future specialists for pedagogical design was confirmed.

\section{CONCLUSIONS AND PERSPECTIVES FOR A FURTHER RESEARCH}

The work does not claim a definitive solution to the problem under study. The prospects for further scientific research are connected with the development of a holistic concept of project pedagogical activity in higher education, creation of a structural and functional model of project activity of an educational institution in Ukraine. 
References

1. Dokuchaeva, V.V. (1994). Formation of constructive thinking of the future teacher. Extended abstract of candidate's thesis. Kyiv.

2. Ganopolsky, A.R. (1996). Formation of the professional and pedagogical orientation of future engineers and teachers. Candidate's thesis. Odessa.

3. Gorbatiuk, R.M. (2011). Theoretical and methodological foundations of professional training of future computer engineerseducators. Doctor's thesis. Ternopil.

4. Gromov, E.V. (2007). Formation of pedagogical knowledge and skills of future engineers-educators in the process of teaching computer disciplines. Extended abstract of candidate's thesis. Kharkiv.

5. Gura, S.O. (2004). Organizational and pedagogical conditions for adaptation of future engineers teachers. Extended abstract of candidate's thesis. Kharkiv.

6. Kobernyk, O.M. (2000). Psychological and pedagogical design of the educational process in a rural secondary school. Extended abstract of Doctor's thesis. Kyiv.

7. Podobedova, T.Yu. (2005). Preparing future teachers of the humanities profile for pedagogical design. Extended abstract of candidate's thesis. Lugansk.

8. Potapchuk, O.I. (2016). Formation of readiness of future engineers-educators to professional activity by means of information and communication technologies. Extended abstract of candidate's thesis. Ternopil.

9. Romanovskaya, O.O. (2011). Organizational and pedagogical conditions of preparation of competitive specialist in engineering and pedagogical educational institutions. Extended abstract of candidate's thesis. Kharkiv.

10. Semenikhina O. et al. (2020). The Formation of Skills to Visualize by the Tools of Computer Visualization. Tem JournalTechnology Education Management Informatics, 9(4), 1704-1710. DOI: 10.18421/TEM94-51

11. Semenikhina, O. V., Drushliak, M. G., \& Khvorostina, Y. V. (2019). Use of geogebra cloud service in future math teachers' teaching. Information Technologies and Learning Tools, 73(5), 48-66.

12. Semenikhina, O. V., Semenog, O. M., \& Drushliak, M. H. (2018). Forming of the future teachers' abilities to choose software rationally: praxeology approach. Information Technologies and Learning Tools, 63(1), 230-241. doi:10.33407/itlt.v63i1.1820

13. Semenikhina, O. V., Yurchenko, A. O., Sbruieva, A. A., Kuzminskyi, A. I., Kuchai, O. V., \& Bida, O. A. (2020). The open digital educational resources in it-technologies: quantity analysis. Information Technologies and Learning Tools, 75(1), 331-348.

14. Semenikhina, O., Drushlyak, M. (2017). Principle Of Cognitive Visualization And Its Use In Teaching Mathematics. Physical and Mathematical Education, 3(13), 136-140.

15. Semenikhina, O., Yurchenko, A., Udovychenko, O. (2020). Formation of skills to visualize of future physics teacher: results of the pedagogical experiment. Physical and Mathematical Education, 1(23), 122-128. DOI: 10.31110/2413-1571-2020-023-1020.

16. Semenog, O., Yurchenko, A., Udovychenko, O., Kharchenko, I., \& Kharchenko, S. (2019). Formation of Future Teachers' Skills to Create and Use Visual Models of Knowledge. Tem Journal-Technology Education Management Informatics, 8(1), 275-283. doi:10.18421/tem81-38

17. Skvarok, M.Yu. (2015). Professional training of future engineers-educators in the design of clothing by means of information technologies. Extended abstract of candidate's thesis. Drohobych.

18. Yurchenko, A., Lohvin, A., Lashtun, O., Bezverkha, K., Semenikhina, O. (2017). Visualization Of Learning Material By Means Of FlashTechnologies (For Example The Study Of Trigonometric Functions). Physical and Mathematical Education, 1(11), 128132.

\author{
ПЕДАГОГІЧНИЙ ДИЗАЙН I ПІДГОТОВКА МАЙБУТНІХ ФАХІВЦІВ ЙОГО ВИКОРИСТОВУВАТИ \\ О.В. Семеніхіна, А.О. Юрченко, О.М. Удовиченко, О.В. Литвиненко \\ Сумський державний педагогічний універисеттут імені А.С. Макаренка, Україна
}

Анотація.

Постановка проблеми. У статті описаний український досвід підготовки майбутніх фахівців до педагогічної дизайну.

Матеріали і методи: теоретичні: аналіз і систематизація наукових джерел, педагогічне моделювання для обгрунтування і розроблення моделі формування готовності майбутніх фахівців до педагогічного дизайну; емпіричні: діагностичні для з'ясування ефективності педагогічних умов формування готовності майбутніх фахівців до педагогічного дизайну; педагогічний експеримент (констатувальний, формувальний) - для перевірки ефективності моделі формування готовності майбутніх фахівців до педагогічного дизайну; статистичний - аналіз отриманих даних за допомогою методів математичної статистики для обробки та інтерпретації експериментальних результатів.

Результати. Схарактеризовано стан розвитку проблеми в теорії і практиці професійної освіти України, наведено суперечності, яік на сьогодні не вирішені в галузі підготовки фахіців до педагогічного дизайну, уточнено сутність і структуру готовності майбутніх фахівців до педагогічного дизайну; описані засоби діагностики для визначення рівня готовності; розроблено й теоретично обгрунтовано модель формування готовності майбутніх фахівців до педагогічного дизайну; описані результати статистичного аналізу ї̈ ефективності.

Висновки. Підтверджено ефективність розробленої моделі формування готовності майбутніх фахівців до педагогічного дизайну. Перспективи подальших наукових досліджень пов'язані з розробкою цілісної концепції проектної педагогічної діяльності у вищій школі.

Ключові слова: педагогічне проектування, підготовка майбутніх фахівців, підготовка, професійне навчання, модель. 